$$
\text { CONF- } 961202-29
$$ \\ EFFECT OF DIFFERENT GLASS AND ZEOLITE A COMPOSITIONS ON THE LEACH RESISTANCE OF CERAMIC WASTE FORMS ${ }^{*}$
}

M. A. Lewis, M. Hash, and D. Glandorf Argonne National Laboratory Chemical Technology Division 9700 South Cass Avenue

Argonne, IL 60439

(630) $252-9832$

$$
\text { ANL/CMT/C P. } 90884
$$

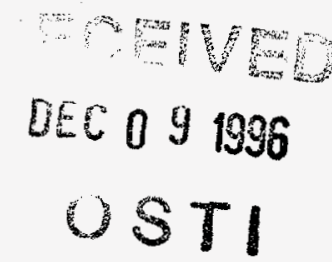

The submitted manuscript has been authored by a contractor of the U.S. Government under contract No. W-31-109-ENG-38. Accordingly, the U.S. Government retains a nonexclusive, royalty-free license to publish or reproduce the published form of this contribution, or allow others to do so, for U.S. Government purposes.

\section{MASTER}

To be Presented at:

Material Research Society Symposium

Boston, MA

December 1-6, 1996

\footnotetext{
"Work supported by the U.S. Department of Energy, Nuclear Energy Research and Development Program, under Contract No. W-31-109-Eng. 38.
} 


\section{DISCLAIMER}

Portions of this document may be illegible in electronic image products. Images are produced from the best available original document. 


\title{
EFFECT OF DIFFERENT GLASS AND ZEOLITE A COMPOSITIONS ON THE LEACH RESISTANCE OF CERAMIC WASTE FORMS
}

\author{
M. A. Lewis, M. Hash, and D. Glandorf, Argonne National Laboratory, Chemical Technology \\ Division, Argonne, IL 60439
}

\section{ABSTRACT}

A ceramic waste form is being developed at Argonne National Laboratory for waste generated during the electrometallurgical treatment of spent nuclear fuel. The waste is generated when fission products are removed from the electrolyte, $\mathrm{LiCl}-\mathrm{KCl}$ eutectic. The ceramic waste form is a composite, fabricated by hot isostatic pressing a mixture of glass frit and zeolite occluded with fission products and salt. Past work has shown that the normalized release rate (NRR) is less than $1 \mathrm{~g} / \mathrm{m}^{2} \mathrm{~d}$ for all elements in a Material Characterization Center-Type 1 (MCC-1) leach test run for 28 days in deionized water at $90^{\circ} \mathrm{C}(363 \mathrm{~K})$. This leach resistance is comparable to that of early Savannah River glasses. We are investigating how leach resistance is affected by changes in the cationic form of zeolite and in the glass composition. Composites were made with three forms of zeolite A and six glasses. We used three-day ASTM C1220-92 (formerly MCC-1) leach tests to screen samples for development purposes only. The leach test results show that the glass composites of zeolites $5 \mathrm{~A}$ and $4 \mathrm{~A}$ retain fission products equally well. The loss of cesium is small, varying from 0.1 to $0.5 \mathrm{wt} \%$, while the loss of divalent and trivalent fission products is one or more orders of magnitude smaller. Composites of $5 \mathrm{~A}$ retain chloride ion better in these short-term screens than $4 \mathrm{~A}$ and $3 \mathrm{~A}$. The more leach resistant composites were made with durable glasses that were rich in silica and poor in alkaline earth oxides. The x-ray diffraction (XRD) results show that a salt phase was absent in the leach resistant composites of $5 \mathrm{~A}$ and the better glasses but was present in the other composites with poorer leach performance. Thus, the data show that the absience of a salt phase in a composite's XRD pattern corresponds to improved leach resistance. The data also suggest that the interactions between the zeolite and glass depend on the composition of both.

\section{INTRODUCTION}

A ceramic waste form is being developed at Argonne National Laboratory for waste generated during the electrometallurgical treatment of spent nuclear fuel. The waste is generated when fission products are removed from the electrolyte, $\mathrm{LiCl}-\mathrm{KCl}$ eutectic, used in the electrorefining step.

Early samples of the ceramic waste form were fabricated by hot uniaxially pressing a mixture of glass frit and zeolite occluded with fission products and salt $[1,2]$. The leach resistance of the resulting waste form was evaluated with the Material Characterization Center-Type 1 (MCC-1) leach tests [3]. Most tests were run for 28 days in deionized water at $90^{\circ} \mathrm{C}(363 \mathrm{~K})$, though a few were run in simulated J-13 well water and brine. Under these test conditions, all elements in the ceramic waste form had a normalized release rate of less than $1 \mathrm{~g} / \mathrm{m}^{2} \mathrm{~d}$, comparable to that measured in 1982 for Savannah River borosilicate glass [4].

Recently, the pressing method was changed from uniaxial to isostatic. This change facilitates fabrication of larger samples. Process parameters were subsequently modified [5]. The temperature was increased from $700-715^{\circ} \mathrm{C}(973-988 \mathrm{~K})$ to $750^{\circ} \mathrm{C}(1025 \mathrm{~K})$, and the pressure from $6000 \mathrm{psi}$ (41 Mpa) to $25.000 \mathrm{psi}(172 \mathrm{MPa}$ ). These conditions were necessary for deformation of the stainless steel can. The time at temperatures above $600^{\circ} \mathrm{C}(873 \mathrm{~K})$ was minimal to prevent the formation of other crystalline phases during hot isostatic pressing. These changes prompted a re-examination of the effect of glass and zeolite compositions on leach resistance.

We are now investigating the leach resistance of ceramic waste forms prepared using three forms of commercially available zeolite $\mathrm{A}$ (designated $5 \mathrm{~A}, 4 \mathrm{~A}$, and $3 \mathrm{~A}$ ). Zeolite $\mathrm{A}$ (all forms) can be represented by the formula, $\mathrm{M}_{12} \mathrm{Al}_{12} \mathrm{Si}_{12} \mathrm{O}_{48}$, where $\mathrm{M}$ represents a univalent charge-compensating cation [6]. The zeolite A structure contains both alpha and beta cages. The size of the pore (entrance) to the alpha cage is determined by the number and charge of the charge-compensating cations. The charge-compensating ions vary in the different forms: $5 \mathrm{~A}$ contains calcium and sodium; $4 \mathrm{~A}$, only sodium; and $3 \mathrm{~A}$, potassium and sodium. The number preceding the letter $\mathrm{A}$ gives the 
nominal pore size for the alpha cage, in angstroms. Different forms of zeolite $A$ have different thermal stabilities. We investigated these zeolites to determine if differences in nominal pore size and/or thermal stability affect the leach resistance of their composites. We are also investigating the leach resistance of ceramic waste forms prepared with several glass compositions. Both the binding properties and durability of the glass are important. The glass matrix binds the zeolite powders and reduces the exposed surface area of the zeolite.

All samples were subjected to ASTM C1220-92 leach tests (the American Society Testing and Materials procedure for MCC-1 leach tests) for three days and examined with XRD. These screening tests allowed us to assess potential performance quickly. Leach resistance was evaluated by monitoring the loss of surrogate fission products, chloride, and boron from composite samples during leaching. Obviously, the most important characteristic of a waste form is its ability to retain fission products. The chloride loss is a measure of the chloride ion retention in the ceramic waste form and the boron loss is a measure of the glass durability. Each ceramic waste form sample was examined with XRD. Patterns obtained by this method were compared with those of the starting materials and other phases. The leach data and the XRD data were compared, and correlations were noted.

\section{EXPERIMENTAL}

\section{$\underline{\text { Materials }}$}

Waste Salt. The materials used in these tests include simulated waste salt, zeolite A, and glass frit. Two waste salt compositions, given in Table I, were used. Both contained about $10 \mathrm{wt} \%$ fission products in $\mathrm{KCl}-44.2 \mathrm{wt} \% \mathrm{LiCl}$ eutectic salt. The simulated fission product chlorides were obtained from Aldrich or Johnson-Matthey. They were $99.9 \%$ purity or better, and all were packed under argon in glass ampoules. The $\mathrm{LiCl}-\mathrm{KCl}$ eutectic salt was obtained from APL Engineered Materials, Inc. (Urbana, IL) and was also packed under an argon atmosphere. The various components were heated at $500^{\circ} \mathrm{C}(773 \mathrm{~K})$ in a furnace well in a dry, ảrgon or helium atmosphere glovebox. After melting, the salt was quenched and then crushed.

Table I. Salt Composition

\begin{tabular}{|c|c|c|c|c|c|c|c|c|c|c|c|}
\hline ID\# & \multicolumn{10}{|c|}{ Component Salts (wt\%) } \\
\hline & $\mathrm{CsCl}$ & $\mathrm{KCl}$ & $\mathrm{LiCl}$ & $\mathrm{NaCl}$ & $\mathrm{BaCl}_{2}$ & $\mathrm{SrCl}_{2}$ & $\mathrm{CeCl}$ & $\mathrm{LaCl}_{3}$ & $\mathrm{NdCl}_{3}$ & $\mathrm{PrCl}_{3}$ & $\mathrm{YCl}_{3}$ \\
\hline Salt 1 & 3.7 & 45.3 & 39.6 & 6.0 & 1.4 & 0.6 & 0.7 & 1.1 & 1.0 & 0 & 0.1 \\
\hline Salt 2 & 2.3 & 48.7 & 40.7 & 0.0 & 1.0 & 0.4 & 1.9 & 0.6 & 3.8 & 0.8 & 0.1 \\
\hline
\end{tabular}

Zeolite. Three commercial forms of zeolite A were used: $5 \mathrm{~A}, 4 \mathrm{~A}$, and $3 \mathrm{~A}$. They were obtained from the UOP-Molecular Sieves Division (Moorestown, NJ). The nominal compositions of the zeolites are given in Table II.

Table II. Zeolite Compositions

\begin{tabular}{|c|c|c|c|c|c|c|}
\hline Zeolite Type & \multicolumn{5}{|c|}{ Components } & (Wt\%) \\
\hline & $\mathrm{Al}$ & $\mathrm{Ca}$ & $\mathrm{K}$ & $\mathrm{Na}$ & $\mathrm{Si}$ & $\mathrm{O}$ \\
\hline $5 \mathrm{~A}$ & 18.1 & 9.7 & $\mathrm{NM}^{\mathrm{a}}$ & 4.4 & 17.9 & Remainder \\
\hline $4 \mathrm{~A}$ & 19.0 & $\mathrm{NM}^{\mathrm{a}}$ & $\mathrm{NM}^{\mathrm{a}}$ & 16.2 & 19.8 & Remainder \\
\hline $3 \mathrm{~A}$ & 16.5 & $\mathrm{NM}^{\mathrm{a}}$ & 10.1 & 8.0 & 16.3 & Remainder \\
\hline
\end{tabular}

nM $=$ not measured.

Glass. Six glass frits were tested. All were aluminoborosilicate glasses. These proprietary glass formulations are designated as $\mathrm{Gl}, \mathrm{G} 2, \mathrm{G} 3, \mathrm{G} 4, \mathrm{G} 5$, and $\mathrm{G} 6$, and their compositions are given in Table III. The glasses were obtained from either Bayer Chemicals (Baltimore, MD) or Corning (Corning, NY). 
Table III. Glass Compositions

\begin{tabular}{|c|c|c|c|c|c|c|c|c|}
\hline $\mathrm{ID \#}$ & \multicolumn{7}{|c|}{ Glass Components (wt\%) } \\
\hline & $\mathrm{Al}_{2} \mathrm{O}_{3}$ & $\mathrm{~B}_{2} \mathrm{O}_{3}$ & $\mathrm{CaO}$ & $\mathrm{K}_{2} \mathrm{O}$ & $\mathrm{Na}_{2} \mathrm{O}$ & $\mathrm{SiO}_{2}$ & $\mathrm{SrO}$ & $\mathrm{ZrO}_{2}$ \\
\hline $\mathrm{G} 1$ & 8 & 17 & 1 & 1 & 7 & 65 & 0 & 1 \\
\hline $\mathrm{G} 2$ & 10 & 14 & 14 & 1 & 6 & 55 & 1 & 0 \\
\hline $\mathrm{G} 3$ & 6 & 10 & 11 & 1 & 3 & 61 & 8 & 0 \\
\hline $\mathrm{G} 4$ & 3 & 18 & 0 & 9 & 1 & 68 & 0 & 0 \\
\hline $\mathrm{G} 5$ & 6 & 11 & 1 & 1 & 7 & 72 & 0 & 0 \\
\hline $\mathrm{G} 6$ & 9 & 12 & 0 & 6 & 5 & 68 & 0 & 0 \\
\hline
\end{tabular}

Composites. In the following discussion, composites are identified according to zeolite form and glass type. For example, $5 \mathrm{~A} / \mathrm{Gl}$ signifies a composite made with salt-occluded $5 \mathrm{~A}$ zeolite and glass G1. Except where noted, all composites were prepared from mixtures containing equal weights of salt-occluded zeolite and glass. Two composites also contained an additional $10 \%$ dehydrated zeolite. The purpose of this test was to determine if the additional zeolite scavanges non-occluded salt.

Processing

Blending. The salt-occluded zeolite was prepared by mixing dehydrated zeolite and the crushed simulated waste salt in a rotating double-cone blender at $500^{\circ} \mathrm{C}(773 \mathrm{~K})$ [7]. All of the saltoccluded zeolites used in these experiments contained $21 \mathrm{wt} \%$ salt. For simplicity in this text we refer to all of the salt-occluded zeolites by the zeolite form used in the blending process, i.e, $5 \mathrm{~A}, 4 \mathrm{~A}$, or $3 \mathrm{~A}$.

Hot Isostatic Pressing. All composites were hot pressed using a two-step thermal profile that consisted of a temperature increase to $750^{\circ} \mathrm{C}(1023 \mathrm{~K})$ followed by a fast cool down to $600^{\circ} \mathrm{C}$ $(873 \mathrm{~K})$, where the temperature was maintained for one hour. The profiles are discussed in more detail in another paper [5].

Test Method

After hot pressing, cored samples of the composite (ceramic waste form) were leached in deionized water at $90^{\circ} \mathrm{C}(363 \mathrm{~K})$, for three days according to the ASTM C1220-92 procedure. The total mass loss was measured in each test. The leachates were analyzed with a variety of techniques. Chloride ion concentration was measured with a chloride ion selective electrode. Cesium and the rare earth ions were measured with inductively coupled plasma-mass spectroscopy (ICP-MS). The other ions were measured with inductively coupled plasma-atomic emission spectroscopy (ICP-AES). For most leachates, the ICP-AES detection limits were too low for barium $(0.02 \mu \mathrm{g} / \mathrm{mL})$ and strontium $(0.005 \mu \mathrm{g} / \mathrm{mL})$ to be measured. In later tests, ICP-MS was used to measure barium and strontium. In addition, a duplicate sample of each hot-pressed composite was crushed and examined for crystalline phases with XRD.

\section{RESULTS}

$\underline{\text { Leach Tests }}$

The purpose of these experiments was to screen composites made with different zeolites and glasses and to identify the more promising compositions. The most important criterion for the ceramic waste form is that it immobilize fission products. Measurement of fission product loss involves several analyses and is relatively expensive. Therefore, only selected leachates were analyzed for fission products. The fractional loss of cesium is reported in Table IV as a percent. The fractional loss is defined as the ratio of the amount released into the solution relative to the amount initially present. The data are grouped according to zeolite and glass type. The release of fission products was found to depend on valence. Cesium, the only +1 ion, had a higher release than the higher valence fission products. The divalent fission products (barium and strontium) and the 
trivalent fission products (cerium, lanthanum. neodymium, praseodymium, and yttrium) had very low releases, resulting in a concentration of less than $5 \mu \mathrm{g} / \mathrm{L}$ in the leachate. Cesium releases, by way of contrast, were on the order of $200 \mu \mathrm{g} / \mathrm{L}$ in the leachate. Low releases of cesium and very low releases of the divalent and trivalent ions were common to both $5 \mathrm{~A}$ and $4 \mathrm{~A}$. Typical values for the fraction loss, in percent, for the divalent and trivalent ions are given in Table $V$ for $5 \mathrm{~A} / \mathrm{Gl}$ and $4 \mathrm{~A} / \mathrm{Gl}$.

Table IV. Summary of Leach Test and XRD Results for Composites of Salt-Occluded Zeolite and Glass

\begin{tabular}{|c|c|c|c|c|c|}
\hline $\begin{array}{c}\text { Sample } \\
\text { ID } \\
\end{array}$ & \begin{tabular}{|c|}
$\begin{array}{c}\text { Total Mass } \\
\text { Loss }(\%)\end{array}$ \\
\end{tabular} & $\begin{array}{l}\text { Mass Loss } \\
\text { for Cs (\%) }\end{array}$ & $\begin{array}{l}\text { Mass Loss } \\
\text { for B }(\%)\end{array}$ & \begin{tabular}{|l|} 
Mass Loss \\
for Cl $(\%)$ \\
\end{tabular} & Phases in XRD Patterns \\
\hline \multicolumn{6}{|l|}{$5 A / G 1$} \\
\hline $\mathrm{HO} 373$ & 0.12 & 0.19 & 0.05 & 0.59 & zeolite \\
\hline $\mathrm{HO} 424$ & 0.16 & 0.23 & 0.05 & 0.96 & zeolite \\
\hline HO452 & 0.11 & 0.23 & 0.05 & 0.37 & zeolite \\
\hline HO521 & 0.12 & 0.30 & 0.09 & 0.45 & zeolite \\
\hline HO624 & 0.12 & 0.10 & 0.04 & 0.62 & zeolite \\
\hline HO653 & 0.09 & 0.46 & 0.04 & 0.49 & zeolite \\
\hline HO721 & 0.07 & 0.48 & 0.14 & 0.32 & zeolite \\
\hline $\mathrm{HO} 741$ & 0.12 & 0.36 & 0.09 & 0.51 & zeolite \\
\hline $\mathrm{HO}_{443^{\mathrm{a}}}$ & 0.09 & 0.26 & 0.04 & 0.37 & zeolite \\
\hline \multicolumn{6}{|l|}{$5 \mathrm{~A} / \mathrm{G} 2$} \\
\hline 371 & 0.23 & 0.22 & 0.38 & 0.60 & zeolite \\
\hline 453 & 0.85 & $\mathrm{NM}^{6}$ & 0.31 & 0.89 & other + salt \\
\hline \multicolumn{6}{|c|}{ 5A/G3, 5A/G4, 5A/G5, 5A/G6 } \\
\hline $451(\mathrm{G} 3)$ & 0.48 & $\mathrm{NM}^{6}$ & 0.68 & 0.92 & other + salt + sodalite \\
\hline $832(\mathrm{G} 4)$ & 0.26 & 0.20 & 0.51 & 0.30 & zeolite \\
\hline $834(\mathrm{G} 5)$ & 0.12 & 0.25 & 0.02 & 0.45 & zeolite \\
\hline 835 (G6) & 0.17 & 0.30 & $\mathrm{ND}^{\mathrm{c}}$ & 0.44 & zeolite + other \\
\hline \multicolumn{6}{|l|}{ 4A/G1 } \\
\hline 423 & 0.26 & 0.20 & 0.10 & 1.09 & zeolite + salt \\
\hline $471^{\mathrm{d}}$ & 0.36 & 0.48 & 0.12 & 0.88 & zeolite + salt \\
\hline \multicolumn{6}{|l|}{$\overline{4 A / G 2}$} \\
\hline 421 & 0.44 & $\mathrm{NM}^{\mathrm{b}}$ & $\mathrm{NM}^{\mathrm{b}}$ & 1.60 & zeolite + salt \\
\hline $472^{d}$ & 0.43 & 0.40 & 0.35 & 0.85 & zeolite + salt + sodalite \\
\hline \multicolumn{6}{|l|}{ 3A/G1 } \\
\hline 491 & 0.57 & NM & NM & 1.67 & zeolite + salt \\
\hline
\end{tabular}

${ }^{\mathrm{a} S a m p l e ~ c o n t a i n s} 45 \%$ glass.

${ }^{\mathrm{b} M}=$ not measured.

${ }^{\mathrm{N} D}=$ not detected.

${ }^{\mathrm{d}} 10 \%$ dehydrated zeolite was added to zeolite/glass frit mixture prior to hot pressing.

Table V. Fractional Loss of Divalent and Trivalent Ions from 5A/G1 and 4A/G1

\begin{tabular}{|c|c|c|c|c|c|c|c|}
\hline ID \# & Zeolite/Glass & \multicolumn{5}{|c|}{ Fractional Loss of Higher Valent Ions } \\
\hline & & $\mathrm{Ba}$ & $\mathrm{Sr}$ & $\mathrm{Ce}$ & $\mathrm{La}$ & $\mathrm{Nd}$ & $\mathrm{Y}$ \\
\hline 424 & $5 \mathrm{~A} / \mathrm{G} 1$ & $\mathrm{BDL}^{\mathrm{a}}$ & $\mathrm{BDL}^{\mathrm{a}}$ & 0.001 & 0.000 & 0.001 & 0.003 \\
\hline 423 & $4 \mathrm{~A} / \mathrm{G} 1$ & $\mathrm{BDL}^{\mathrm{a}}$ & $\mathrm{BDL}^{\mathrm{a}}$ & 0.012 & 0.001 & 0.015 & 0.001 \\
\hline
\end{tabular}

${ }^{\mathrm{a}} \mathrm{BDL}=$ below detection limit of $0.02 \mu \mathrm{G} / \mathrm{mL}$ for $\mathrm{Ba}$ and $0.005 \mu \mathrm{G} / \mathrm{mL}$ for $\mathrm{Sr}$ 
The total mass loss was used as a quality screen. On this basis, three zeolite/glass combinations stand out (5A/G1, 5A/G5, and 5A/G6). All of their mass losses were less than $0.2 \%$. One combination $5 \mathrm{~A} / \mathrm{Gl}$ was studied extensively. Nine samples were prepared using several batches of $5 \mathrm{~A}$ and several lots of glass frit. The mass losses were consistently low. The average for the $5 \mathrm{~A} / \mathrm{G} 1$ composites was $0.11 \%$ with a standard deviation of $0.03 \%$. Two other combinations, $5 \mathrm{~A} / \mathrm{G} 5$ and $5 \mathrm{~A} / \mathrm{G} 6$, also had low mass losses in initial tests. The mass loss for all the other samples shown in Table IV varied from 0.2 to $0.9 \%$, indicating that both zeolite and glass compositions affect leach resistance. For example, Gl composites with $4 \mathrm{~A}$ and $3 \mathrm{~A}$ had higher mass losses $(0.3-0.6 \%)$ than with $5 \mathrm{~A}$. Likewise, 5A composites with G2 and G3 had higher mass losses $(0.2-0.9 \%)$ than with G1. Possible reasons for the variation in mass losses include differences in the release of chloride and fission products and in the durability of the glass. Fractional losses for chloride, fission products, and boron were examined to gain insight into the leaching mechanisms.

The release of chloride is used to measure chloride dissolution. There are two sources of chloride: one from occluded salt within the zeolite's cages, and the other from "free" salt, which is sometimes seen in XRD patterns of the composites. In general, high chloride losses correlate with high total mass losses (e.g., see 4A/G2 and 3A/G1 composites in Table IV) and, as discussed below, generally track with the presence of "free" salt in the XRD pattern. This suggests chloride loss can be an important leaching mechanism. The data also show that the different forms of zeolite A have different chloride retention properties. The 5A/G1 composites had consistently lower chloride releases than the $4 \mathrm{~A} / \mathrm{G} 1$ and $3 \mathrm{~A} / \mathrm{Gl}$ composites. The $5 \mathrm{~A} / \mathrm{G} 2$ composites also had lower chloride releases than the $4 \mathrm{~A} / \mathrm{G} 2$ composites. Thus, $5 \mathrm{~A}$ retains salt better than $4 \mathrm{~A}$ and $3 \mathrm{~A}$, for the glasses tested. Additional work was recently started with $5 \mathrm{~A}$ and other aluminoborosilicate glasses (G3-G6). As shown in Table IV, composites with G4, G5, and G6 had low chloride releases, whereas the composite with $\mathrm{G} 3$ had a relatively high release.

Comparison of the compositions of the zeolites, salt, and glasses shows that boron is the only major element present in the glass phase that is not present in the zeolite. Thus, the boron release provides an approximate measure of glass dissolution. The following data confirm that boron loss is a reasonable measure of glass durability. Leach tests of the pure G1 and G2 glasses showed that G1 was more durable than G2. The mass losses measured after a 3-day leach test for pure, hot isostatically pressed glasses were essentially $0 \%$ for $\mathrm{G} 1$ and $0.24 \%$ for $\mathrm{G} 2$. The releases from $\mathrm{G} 1$ glass of aluminum and silicon were very low, 0.00 and $0.03 \%$, respectively. For G2, the releases of aluminum and silicon were significantly higher, 0.26 and $0.27 \%$, respectively. As shown in Table IV, the fraction of boron leached was lower for G1 composites than for G2 composites, indicating that G1 is more durable in composites than $\mathrm{G} 2$. The durability of $\mathrm{G} 3, \mathrm{G} 4, \mathrm{G} 5$, and $\mathrm{G} 6$ has not been as extensively investigated as G1 and G2. The limited data in Table IV show boron releases were very low for G5 and G6, and these glasses appear promising for further testing.

The data in Table IV also show that the boron release was lower for $5 \mathrm{~A} / \mathrm{G} 1$ composites than for $4 \mathrm{~A} / \mathrm{G} 1$ composites. Thus, the form of the zeolite affects the performance of $\mathrm{Gl}$ composites.

\section{$\underline{\text { X-ray Diffraction Results }}$}

Sister samples of the leached composites were examined with XRD. These patterns were compared with each other and with the starting materials used in their fabrication. This comparison showed that the composites could be divided into one of three types, according to the predominant crystalline phases. The three types are (1) zeolite, where the pattern of the composite is almost the same as the pattern of the initial zeolite, and there are no additional phases, (2) other, which designates unidentified phases, and (3) a mixture of zeolite, "free" salt, and, in some cases, sodalite. The phases identified in the XRD pattern for each composite are given in Table IV.

Figure $1 \mathrm{~A}$ is the XRD pattern of $5 \mathrm{~A}$ with 21 wt\% salt. Figure $1 \mathrm{~B}$ is the XRD pattern of a $5 \mathrm{~A} / \mathrm{G} 1$ composite. All of the XRD patterns for the $5 \mathrm{~A} / \mathrm{G} 1$ composites were similar. The $5 \mathrm{~A} / \mathrm{G} 5$ and 5A/G6 composites were also of this type. (The 5A/G6 composite contained an additional unidentified phase.) In Figure $1 \mathrm{~B}$, there is a broad, amorphous peak (between 20-30 ) due to the glass component of the composite. Further comparison of Figures $1 \mathrm{~A}$ and $\mathrm{BB}$ shows that the two patterns are alike in some respects and different in others. For example, the positions of the lines present in both patterns are essentially the same. However, the relative intensities of some lines are very different. One strong line and several weak ones present in Figure IA are absent in Figure IB. 

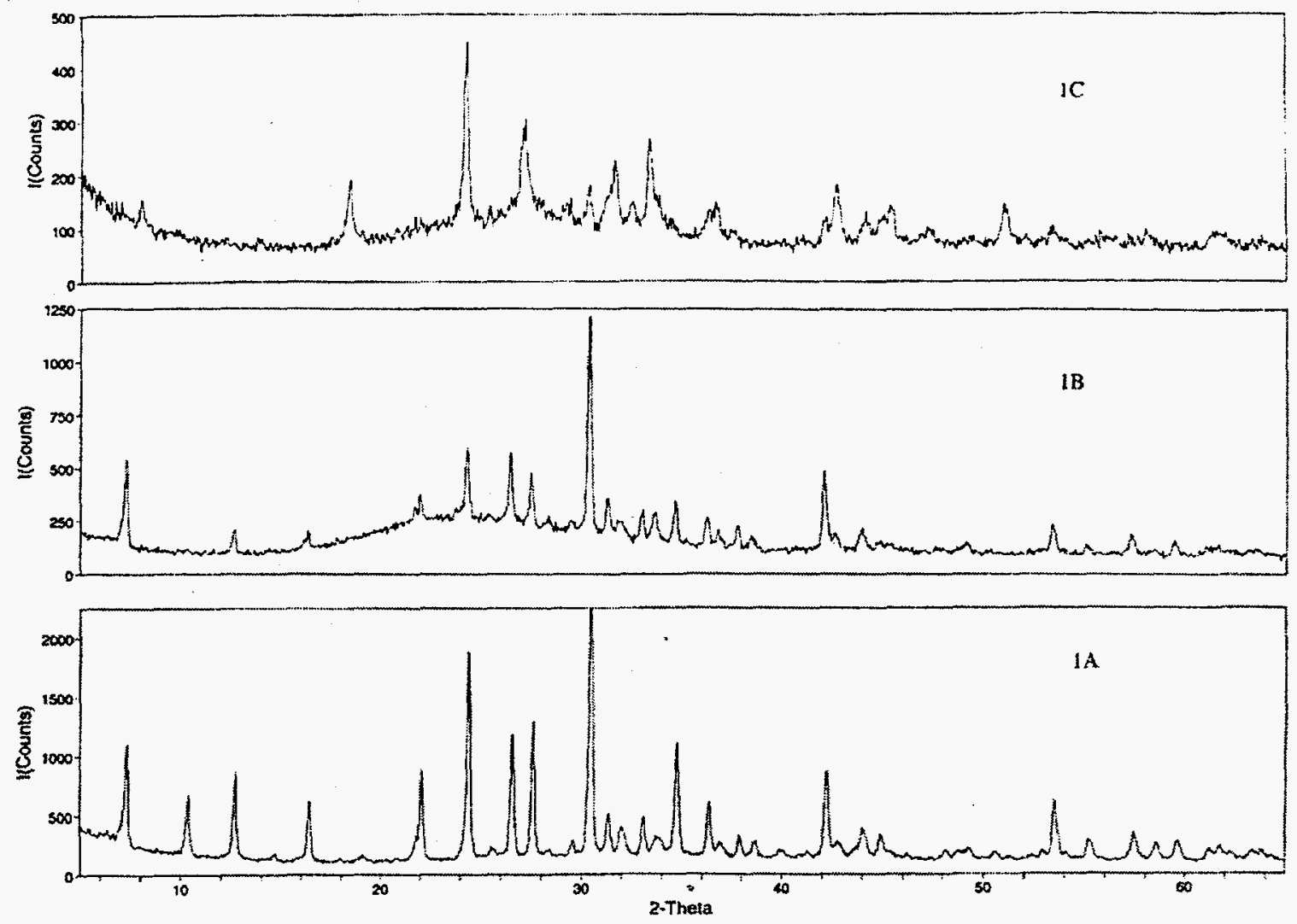

Fig. 1. X-ray Diffraction Patterns of $5 A$ with 21 wt\% salt (A) and Two Zeolite-Glass Composites, B (5A/G1, \#452) and C (5A/G2, \#453)

Figure $1 \mathrm{C}$ is an example of a XRD pattern that consists of "other" phases, and very little, if any, zeolite phase. This can be seen by comparing Figure 1A with Figure 1C, the XRD pattern for a $5 A / G 2$ composite, \#453. There is no longer a one-to-one correspondence between the positions of the lines in the XRD patterns for the composite and the zeolite. The XRD pattern of the 5A/G3 composite was also of this type. The "other" phases in these composites are, as yet, unidentified. Easily identified phases such as $\mathrm{NaCl}$ or sodalite were present in some of these composites. Samples with these phases are identified in Table IV.

The data indicate that the zeolite-glass interactions depend on glass composition. For example, three of the composites $5 \mathrm{~A} / \mathrm{G} 1,5 \mathrm{~A} / \mathrm{G} 2$, and $5 \mathrm{~A} / \mathrm{G} 3$ (\#451, \#452, and $\# 453$, respectively) had different XRD patterns even though they were made in the same hot pressing run and with the same batch of $5 \mathrm{~A}$. Glasses 2 and 3 interacted more strongly with $5 \mathrm{~A}$ and caused it to transform to other crystalline phases. Glass 1 showed less tendency to effect a transformation of the zeolite.

A comparison of the XRD patterns for $4 \mathrm{~A}$ and its composites, $4 \mathrm{~A} / \mathrm{G} 1$ and $4 \mathrm{~A} / \mathrm{G} 2$ showed that the patterns of the composites consisted of mixtures of zeolite, $\mathrm{NaCl}$, and, in some, cases, sodalite. The same changes in the zeolite patterns observed in the $5 \mathrm{~A}$ and $5 \mathrm{~A} / \mathrm{G} 1$ composites were also seen in the $4 \mathrm{~A}$ samples. There was a one-to-one correspondence in the positions of the zeolite lines but relative intensities of some lines varied. Similar results were seen in the XRD patterns for $3 \mathrm{~A}$ and the $3 \mathrm{~A} / \mathrm{Gl}$ composite.

Thus, the XRD results suggest that composites made from $5 \mathrm{~A}$ are less likely to convert to other phases than those made from $4 \mathrm{~A}$. We have studied the effect of heating mixtures of $5 \mathrm{~A} / \mathrm{Gl}$ and $4 \mathrm{~A} / \mathrm{G} 2$ powders (prior to hot pressing) at $700^{\circ} \mathrm{C}(973 \mathrm{~K})$. The $4 \mathrm{~A} / \mathrm{G} 2$ mixtures completely converted to sodalite within 4 hours, while the $5 \mathrm{~A} / \mathrm{G} 1$ mixture did not convert to sodalite, even after 24 hours. 
The XRD results also show that differences in promoting transformation exist among various glasses. Examination of the compositions in Table III shows that the glasses that react with $5 \mathrm{~A}$ (G2 and G3) contain more than 10\% alkaline earth oxides. Glasses that are less aggressive contain $1 \%$ or less alkaline earth oxides.

\section{CONCLUSIONS}

Composites comprised of zeolite A containing $21 \mathrm{wt} \%$ salt and glass frit were hot isostatically pressed and then leached. Three forms of zeolite A and six glass frits were used. We investigated the effect of compositional changes in the zeolite and the glass by measuring short term leach resistance and crystal structure. The results were the following. First, both zeolite $5 \mathrm{~A}$ and $4 \mathrm{~A}$ retain fission products equally well. The release of cesium was small, varying from 0.1 to $0.5 \mathrm{wt} \%$, while the release of divalent and trivalent fission products was one or more orders of magnitude smaller. Second, 5A/GI composites retained chloride better than 4A/GI and 3A/G1 composites. The chloride loss was especially high for the $3 \mathrm{~A} / \mathrm{Gl}$ composite. Third, several aluminoborosilicate glasses (G1, G5, and G6) acted as durable glass binders for 5A. The other aluminoborosilicate glasses either reacted with the $5 A$ and transformed its XRD pattern $(G 2, G 3)$ or were not durable (G4). Finally, test results correlated with the XRD results, i.e., the leach resistance was usually poor when the XRD pattern contained "free" salt, non-zeolitic phases, or sodalite.

Future work will be concerned with measuring the leach resistance for the more promising zeolite-glass composites for longer times. It is important to determine if the trends observed in the 3-day tests are also observed in tests for 28 days or longer. Other planned experiments are concerned with identifying conditions that affect glass reactivity, such as alkaline earth oxide concentration, and identifying other phases that immobilize cesium better.

\section{REFERENCES}

[1] M. A. Lewis, D. F. Fischer and C. D. Murphy, "Properties of Glass-Bonded Zeolite Monoliths," Environmental and Waste Management Issues in the Ceramic Industry II, Am. Ceram. Soc., Westerville, OH, pp. 279-286 (1994).

[2] M. A. Lewis, D. F. Fischer, and C. D. Murphy, "Densification of Salt-Occluded Zeolite A Powders to a Leach Resistant Monolith," Scientific Basis for Nuclear Waste Management, Eds., A. Barkatt and R. Van Konynenburg, Vol. 333, pp. 277-284, Materials Research Society, Pittsburgh, PA (1994)

[3] "Standard Test Method for Static Leaching of Monolithic Waste Forms for Disposal of Radioactive Waste," ASTM C1220-92, American Society for Testing and Materials, Philadelphia, PA (1995)

[4] M. J. Plodenic, G. G. Wicks, and N. E. Bibler, An Assessment of Savannah River Borosilicate Glass in the Repository Environment, DP-1629, Savannah River Laboratory, Aiken SC (1982).

[5] M. C. Hash, C. Pereira, M. A. Lewis, R. J. Blaskovitz, V. Zyryanov, and J. P. Ackerman, "Hot Isostatic Pressing of Glass-Zeolite Composites," to be published in Environmental Issues and Waste Management Technologies in the Ceramic and Nuclear Industries (1996).

[6] D. W. Breck, Zeolite Molecular Sieves, John Wiley \& Sons, New York (1974).

[7] C. Pereira, V. N. Zyryanov, M. A. Lewis, and J. P. Ackerman, "Mixing of Zeolite Powders and Molten Salt," to be published in Environmental Issues and Waste Management Technologies in the Ceramic and Nuclear Industries (1996). 